\title{
Zpupný krákal - Shakespeara pro naši dobu
}

\author{
Filip Krajník
}

The Upstart Crow. Scénář Ben Elton, režie Sean Foley, hrají David Mitchell, Gemma Whelanová, Mark Heap aj. Premiéra 7. února 2020 v Gielgud Theatre, Londýn, plánovaná derniéra 25. dubna 2020 (poslední představení před uzavřením divadla 15. března 2020). Psáno na základě představení 22 . února 2020.

Závěrem své klasické studie o Shakespearově reputaci od konce 16 . po konec 20. století Shakespeare's Lives Samuel Schoenbaum píše: „Každá generace si musí znovu interpretovat dokumentární záznamy [o Shakespearovi] skrze vlastní prizma a cíle a stanovit vztah mezi člověkem a maskami ve hrách a sonetech" (SCHOENBAUM 1993: 568, překlad F. K.). Každá doba měla svého Shakespeara, který odpovídal jejím problémům, ideálům a zkušenostem. Ve své nedávné publikaci, příznačně nazvané In Our Own Image: Fictional Representations of William Shakespeare David Livingstone hovoří o „dráždivě prázdném listu [the irritating blank slate], kterým je Shakespeare“, na nějž s oblibou projektujeme vlastní představy ani ne tak o tom, jaký Shakespeare doopravdy byl, jako spíše jaký by podle nás měl být (LIVINGSTONE 2019: 325, překlad F. K.). Shakespeare $\mathrm{k}$ nám promlouvá a vyjadřuje se $\mathrm{k}$ aktuálním společenským problémům nejen skrze své hry a jejich stále nové překlady, inscenace a adaptace, ale také skrze své mnohdy fiktivní životy, jež na jedné straně upevňují dramatikovu pozici kulturní ikony a na straně druhé $\mathrm{z}$ něj znovu a znovu činí našeho vrstevníka, sdílejícího s námi naše každodenní starosti a dilemata.

Od jubilejního roku 2016 (400 let od úmrtí Shakespeara) se objevilo hned několik fiktivních „životopisů“, které si vytkly za cíl představit Shakespeara-člověka divákovi 21. století. V roce 2017 měla premiéru první (a jediná) sezóna seriálu Will americké stanice TNT, která především dospívajícím divákům představila mladého Williama Shakespeara v prostředí genderově, etnicky i sexuálně pestrého Londýna, v němž zuří náboženská nesnášenlivost, ženy bojují o spravedlivé uznání a navštěvovat divadlo je „cool“ a „punk“. Na konci roku 2018 americká kina uvedla historické drama All Is True (v ČR kinopremiéra neproběhla) napsané Benem Eltonem (který je českému divákovi známý především jako jeden z autorů historického sitcomu Černá zmije) a režírované Kennethem Branaghem, v němž Branagh ztvárnil stárnoucího Shakespeara, který se po návratu z Londýna do rodného Stratfordu roku 1613 setkává s chladným přijetím ze strany rodiny (Shakespearovu manželku Annu Hathawayovou ztvárnila Judi Denchová) a zjištuje, že na rozdíl od světa divadelních her není ve skutečném životě pravda vše, čemu chceme věřit. Konečně od roku 2016 vysílá britská stanice BBC sitcom Bena Eltona Upstart Crow (u nás jej uvedla ČT v překladu Alžběty Šáchové jako Zpupný krákal), v němž je Shakespeare (komik David Mitchell) vyobrazený jako nespokojený a nedoceněný příslušník střední třídy, trpící komplexy kvůli svému nízkému původu a nedostatku formálního vzdělání a vehementně se snažící vyšplhat po společenském žebříčku, v čemž mu brání jak 


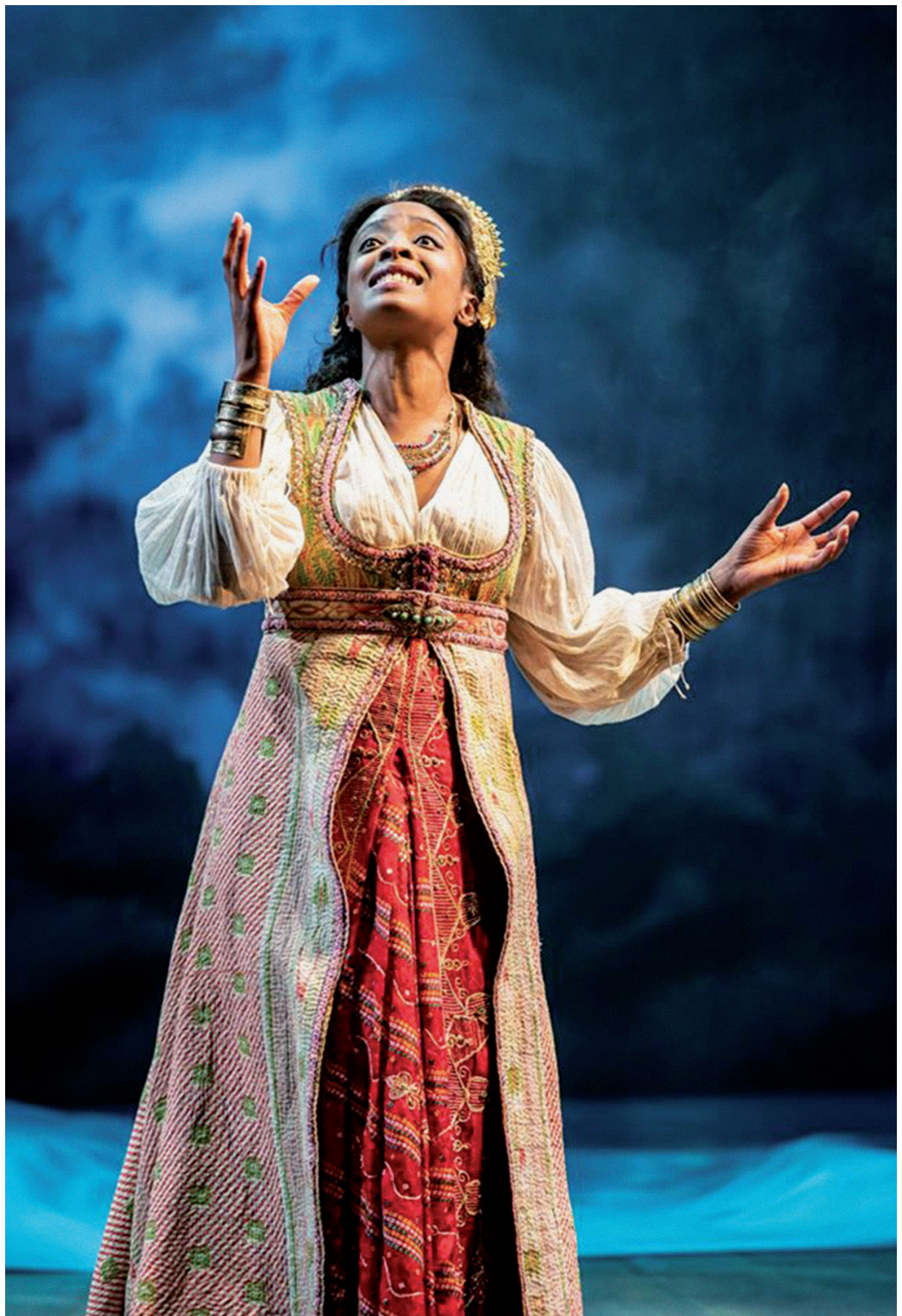

Obr. 1: Rachel Summersová jako princezna Desiree. 
jeho protivníci (např. dramatik Robert Greene v podání Marka Heapa), tak přátelé (např. Christopher Marlowe v podání Tima Downieho). Jako opakující se vtip seriálový Shakespeare v každé epizodě přejíždí mezi Stratfordem a Londýnem a ve stylu moderního pasažéra si v dlouhých monolozích stěžuje na nespolehlivost hromadné dopravy ( $\mathrm{v}$ tomto ohledu současný český divák snadno souzní s tím britským). Podobně vděčným zdrojem humoru je postava dcery Shakespearovy domácí Kate (Gemma Whelanová), která vášnivým bojem za rovnoprávnost žen na konci 16 . století upozorňuje na sexismus v současné společnosti a jejíž (zejména umělecké) ambice neustále narážejí na nepochopení ze strany jejích mužských společníků (včetně Shakespeara).

Po třech úspěšných sériích (seriál obdržel několik televizních cen a nominací, např. na cenu BAFTA či cenu britské Královské televizní společnosti) a dvou vánočních speciálech se začátkem tohoto roku měl Eltonův Shakespeare na necelé tř̀i měsíce přesunout na West End se samostatným příběhem odehrávajícím se necelých deset let po zatím poslední epizodě seriálu. Stejně jako všechna anglická divadla však musel i londýnský Gielgud Theatre, který představení hostil, $\mathrm{z}$ epidemických důvodů v polovině března zavř́t a The Upstart Crow (název hry je od seriálu odlišen jen určitým členem) se dočkal ani ne poloviny plánovaných představení. I tak však inscenace stačila zaznamenat úspěch na straně diváků i kritiků a bylo by s podivem, kdyby autoři nechali potenciál projektu zcela ležet ladem a v budoucnu bychom se nedočkali bud' jeho znovuuvedení, nebo televizní adaptace (podobný osud ostatně potkal televizní revival kultovního britského sitcomu Jistě, pane premiére $\mathrm{z}$ roku 2013, který vycházel z divadelní hry inscenované na West Endu roku 2010).

Převod seriálu Upstart Crow z televizních obrazovek na divadelní jeviště se ukázal jako štastný nápad, a to hned z několika důvodů. Již původní televizní předloha se skromnou výpravou, lacině vyhlížjejícími kulisami a dlouhými, téměř výhradně interiérovými scénami působí velmi divadelně, takže návštěvníci představení (a dá se předpokládat, že většina hostů $\mathrm{v}$ divadle seriál znala) se již od počátku cítili ,jako doma“ a nemuseli si prakticky zvykat na nové médium. Smích živého publika navíc dobře nahrazoval typický sitcomovský smích studiových diváků, před kterými byl původní seriál natáčen, a umocňoval dojem televizní zábavy. Potenciálně odvrácenou stranou přímočaré adaptace seriálu pro jeviště je skutečnost, že až na délku představení zachovává divadelní The Upstart Crow v podstatě beze zbytku formát a podobu původního díla a svému divákovi se nepokouší nabídnout nic víc (ani nic méně), než co by mu poskytla jedna dlouhá epizoda jeho oblíbeného programu během sledování z gauče. Na jednu stranu byla toto od tvůrců inscenace logická volba a většinu příznivců seriálu zřejmě potěšila, na stranu druhou se jednalo snad až př́liš o sázku na jistotu.

Podobně jako jednotlivé díly původního seriálu i The Upstart Crow kopíruje ikonické situace z několika Shakespearových her. Po ztroskotání jejich lodi se do Londýna dostanou dvojčata z egyptského královského rodu, princ Arragon a princezna Desiree, kteří, aniž by o sobě navzájem věděli, postupně oba v přestrojení skončí v Shakespearových službách a zamilují se do dcery jeho bytné Kate (odkaz na Večer třikrálový, méně očividně na Antonia a Kleopatru, později i na Othella). Shakespeare sám trpí 


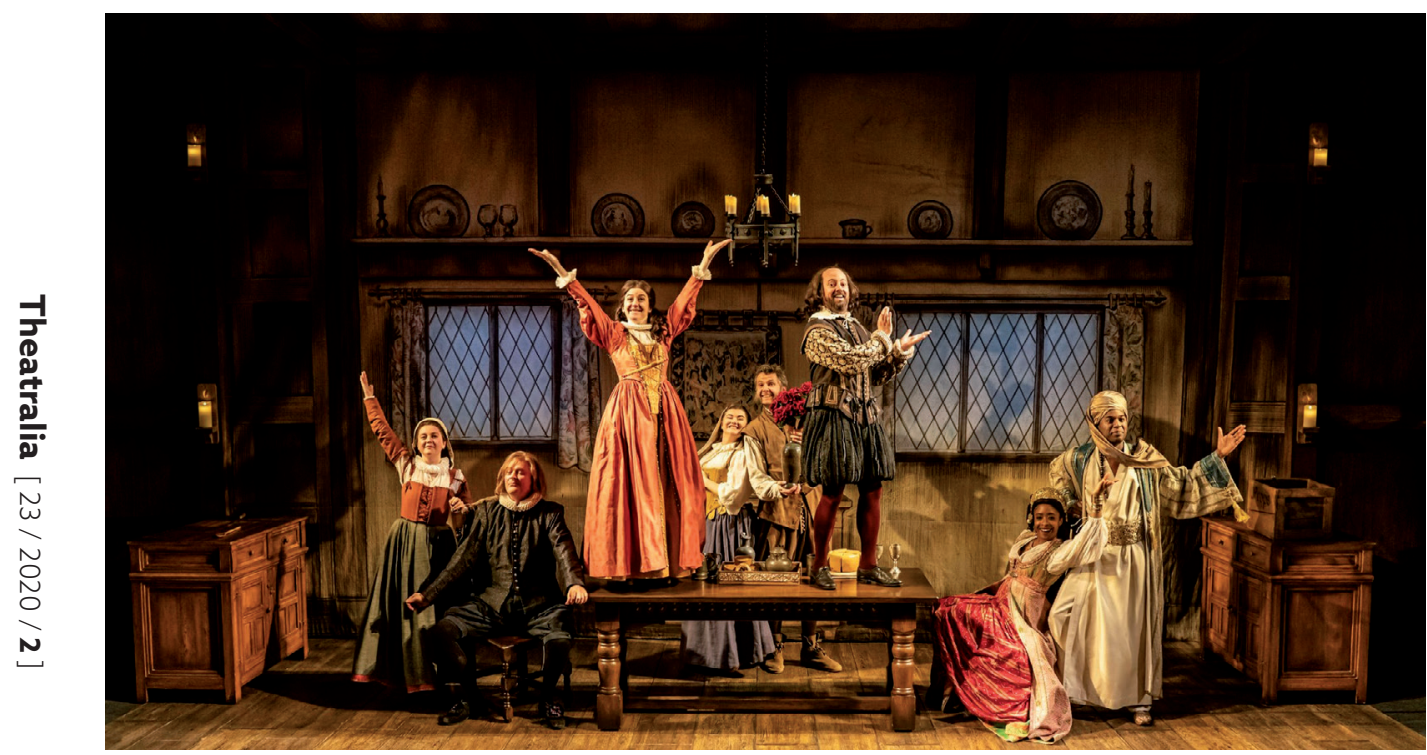

Obr. 2: Helen Monksová, Mark Heap, Gemma Whelanová, Danielle Phillipsová, Rob Rouse, David Mitchell, Rachel Summersová a Jason Callender v The Upstart Crow.

Foto: Johan Persson

melancholií ze smrti svého syna Hamneta a obává se, že se nedokáže zavděčit novému králi (píše se rok 1605, tedy začátek vlády krále Jakuba I.) a napsat pro něj dostatečně „sexuálně transgresivní hru“ s hrdinou, který je cizincem ve většinové společnosti a s nímž by se mohl král Jakub coby Skot ztotožnit - jak požaduje principál Shakespearovy herecké družiny Richard Burbage (Steve Speirs). Pomoc se Shakespeare pokouší najít jednak u puritánského lékaře Johna Halla (který v podání Marka Heapa nahrazuje Shakespearova seriálového arcinepřítele Roberta Greena), ale i v četbě anonymní kronikářské hry o králi Leirovi, která mu vnukne nápad rozdělit své jmění mezi své dcery a nechat se jimi obletovat, zatímco on bude v klidu psát svou hru. Do toho se Kate (jež se stále nevzdala snu stát se herečkou) rozhodne zakročit proti týrání zvířat a z divadla Globe ukradne tančícího medvěda, který nakonec Shakespearovi pomůže splnit jeho sen a inspiruje ho (respektive jeho dcery) k napsání nejlepší jevištní poznámky v dějinách divadla (odkaz na Zimni pohádku).

Vedle variací na známé seriálové vtipy (odkazy na Shakespearovo plagiátorství či na jeho ustupující vlasy) je pro Eltona jedním z nejvěčnějších zdrojů humoru současné lpění na politické korektnosti. Přestože hra sama o sobě nese étos sociální rozmanitosti a spravedlnosti a liberálnúho smýšlení (Elton býval sám politicky aktivní a podporoval britské labouristy a zelené), kdykoliv dostane příležitost, neodpustí si drobný štouchanec např́lklad směrem ke castingu černošských herců v historických dramatech (Desiree na londýnské ulici: „S nadšením zjištuji, že příslušníci černé, asijské a ostatních menšinových etnických skupin se mohli v 16. a 17. století bez povšimnutí procházet po Anglii, jak historická kostýmová dramata v nějaké osvícenější 
době zajisté dosvědčí.“) či identitární politiku (Susanna Shakespearová poté, co ji doktor Hall požádá o ruku: „A určitě jste doktor?“ Dr. Hall: „Ale jistě, protože se tak identifikuji.“). Na paškál si Elton bere i tzv. „kulturu rušení" (Shakespeare ke Kate, vyčítající mu necitlivou sexuální politiku jeho her: „Pokud bys takhle pokračovala, kriminalizovala bys všechny komedie, co jsem kdy napsal.") a na konci hry dojde i na absurdní blackface. Otázkou je, zda by jen o několik měsíců později, kdy zejména v anglosaském světě výrazně stoupla citlivost v otázce reprezentace menšin v umění a společnosti vůbec, publikum podobný humor přijalo se stejným nadšením. Již na konci února neopomenula novinářka Holly Williamsová ve své recenzi pro The Guardian poznamenat, že „vtipy o tom, jak ,uvědomělé‘ [,woke ] se divadlo jednou stane, mě začínaly otravovat”.

Eltonův komický Shakespeare je trochu zabedněný, trochu nabubřelý, trochu zakomplexovaný a velmi nesmělý a na své cestě za nesmrtelností se dopouští jednoho přešlapu za druhým, aby nakonec přece jen došel zasloužené slávy. Pokud se vrátíme $\mathrm{k}$ původní myšlence, že moderní fiktivní životopisy Shakespeara mívají za cíl jednak prriblížit dramatikovu postavu současnému divákovi a jednak upevnit jeho status klasika, (The) Upstart Crow splňuje obě tyto role bezezbytku. Na jedné straně je i pro neanglického diváka snadné se s Eltonovým (a Mitchellovým) Shakespearem identifikovat a těšit se $\mathrm{z}$ toho, že trpí stejnými chybami jako většina $\mathrm{z}$ nás a trápí jej i stejné potíže. Na druhé straně ovšem i v rámci komediálního formátu Elton se Shakespearovým jménem nakládá s úctou a triumfální, vážně zahranou ložnicovou scénou Othella na konci hry divákům připomíná, že Shakespeare byl velikánem, který si zaslouží, aby se o něm psaly knihy, natáčely filmy a psaly (nejen) komediální divadelní hry.

\section{Bibliografie}

LIVINGSTONE, David. 2019. In Our Own Image: Fictional Representations of William Shakespeare. Olomouc: Palacký University, 2019.

SCHOENBAUM, Samuel. 1993. Shakespeare's Lives, New Edition. Oxford: Oxford University Press, 1993.

WILLIAMS, Holly. The Upstart Crow review - a sitcom ripe for a theatrical remake [online]. The Guardian 23. 2. 2020. [cit. 12. 7. 2020]. Dostupné online na https://www.theguardian.com/stage/2020/feb/23/upstart-crow-review-david-mitchell-ben-elton. 